\title{
A real airhead
}

\author{
Declan McDonnell, ${ }^{1}$ Gillian Park ${ }^{2}$
}

${ }^{1}$ Department of Surgery, Southampton General Hospital, Southampton, UK

${ }^{2}$ Department of $A \& E$, Northwick Park Hospital, London, UK

\section{Correspondence to} Declan McDonnell, declan@doctors.org.uk

Accepted 13 November 2014
CrossMark

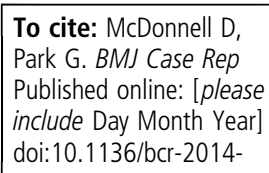

\section{DESCRIPTION}

A 21-year-old man was taken to the emergency department after having fainted. He had hit his head and lost consciousness for a few seconds, and his friends witnessed a shaking episode during this time, although there was no tongue biting or incontinence. He sustained a small laceration above his left eye following the fall. On presentation, he had a worsening headache, felt dizzy and had anterograde amnaesia. Examination was otherwise unremarkable. Given the symptoms, it was decided to perform a CT scan of the head, which showed a marked pneumocephalus, the presence of air inside the head (figure 1).

The CT showed a comminuted hairline fracture extending from the inferior aspect of the left supraorbital ridge, involving the roof of the left orbit and the posterior wall of the frontal sinus (the likely source of the pneumocephalus). A fracture was seen in the greater wing of the sphenoid just adjacent to the superior orbital fissure (figure 2), which provides a conduit between the aforementioned structures and middle cranial fossa.

There were concerns that the amount of air could signify a tension pneumocephalus, or that the fracture could precipitate an infection (especially as it involves the sinus), so the patient was transferred to the nearest neurosurgical centre. He did not develop any signs of raised intracranial pressure, such as fixed pupillary dilation, hypertension or

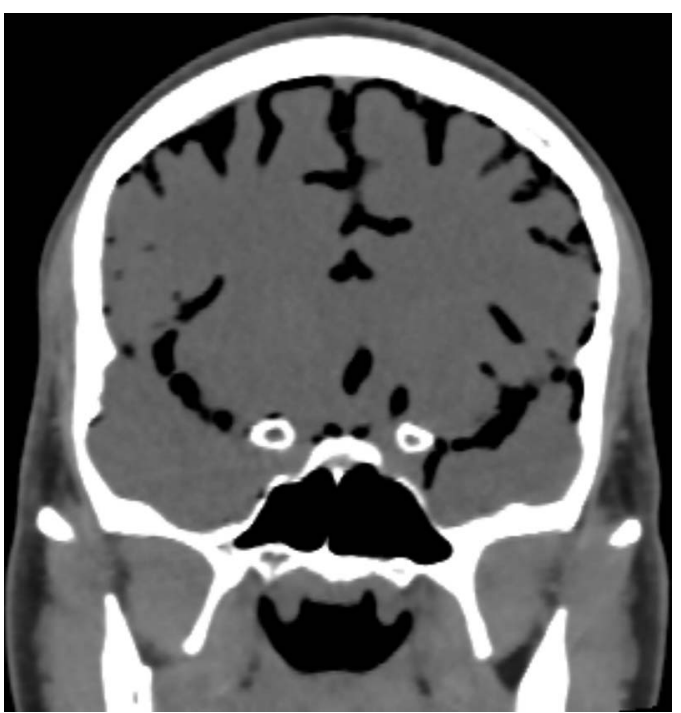

Figure 1 A CT scan showing pneumocephalus.

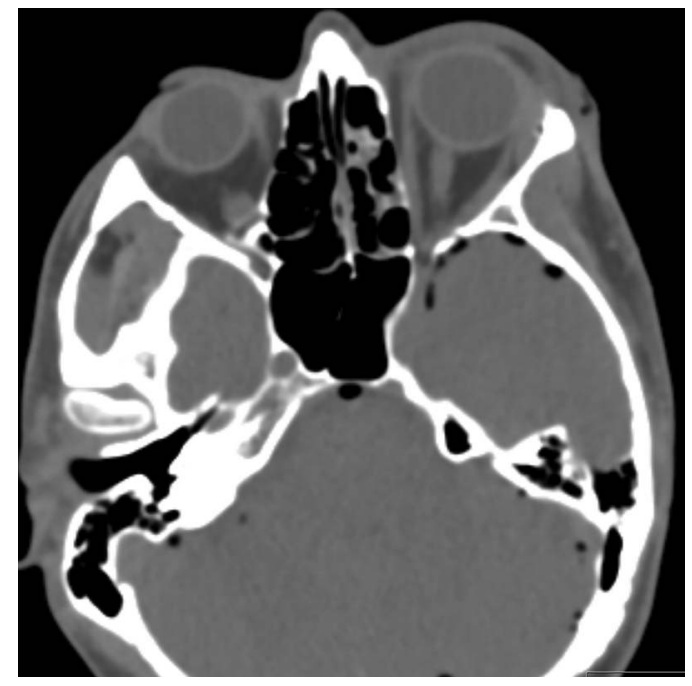

Figure 2 A CT scan showing a fracture in the left greater wing of the sphenoid.

bradycardia, so he was managed conservatively with oxygen therapy. Antibiotics were withheld as he had no evidence of cerebrospinal fluid rhinorrhoea or otorrhoea. He made a full recovery.

\section{Learning points}

- Pneumocephalus is an uncommon complication of traumatic head injury, affecting less than $1 \%$ of head injuries. This figure rises to $8 \%$ when the paranasal sinuses or skull base is involved. $^{1}$

- A tension pneumocephalus should be suspected when the CT shows locules of gas within the ventricular system or basal cisterns. Clinically, they should be monitored for signs of raised intracranial pressure, which would mandate surgical intervention.

- Current evidence does not support routine prophylactic antibiotic usage in fractures affecting the base of the skull, ${ }^{2}$ independent of the presence of cerebrospinal fluid leakage. However, evidence of this clinical sign often influences the decision to use antibiotics such as ceftriaxone, so it is worth investigating local policy. 
Contributors DM drafted and wrote the manuscript. GP oversaw the process. Competing interests None.

Patient consent Obtained.

Provenance and peer review Not commissioned; externally peer reviewed.

\section{REFERENCES}

1 Gill $H S$, van As $A B$. Tension pneumocranium in childhood trauma. World I Pediatr 2008;4:231-3.

2 Ratilal BO, Costa J, Sampaio C, et al. Antibiotic prophylaxis for preventing meningitis in patients with basilar skull fractures. Cochrane Database Syst Rev 2011;(8):CD004884.

Copyright 2014 BMJ Publishing Group. All rights reserved. For permission to reuse any of this content visit

http://group.bmj.com/group/rights-licensing/permissions.

BMJ Case Report Fellows may re-use this article for personal use and teaching without any further permission.

Become a Fellow of BMJ Case Reports today and you can:

- Submit as many cases as you like

- Enjoy fast sympathetic peer review and rapid publication of accepted articles

- Access all the published articles

- Re-use any of the published material for personal use and teaching without further permission

For information on Institutional Fellowships contact consortiasales@bmjgroup.com

Visit casereports.bmj.com for more articles like this and to become a Fellow 